\title{
THE INFLUENCE OF PRODUCTION TECHNOLOGY ON YIELD AND SELECTED QUALITY PARAMETERS OF SPRING WHEAT CULTIVARS
}

\author{
Alicja Sułek ${ }^{1}$, Grażyna Cacak-Pietrzak² \\ ${ }^{1}$ Institute of Soil Science and Plant Cultivation - State Research Institute, Poland \\ ${ }^{2}$ Warsaw University of Life Science, Poland \\ sulek@iung.pulawy.pl
}

\begin{abstract}
The field experiments were conducted at the Institute of Soil Science and Plant Cultivation - State Research Institute Experimental Station in Osiny in the years of 2015 - 2016. The aim of the study was to compare spring wheat (Triticum aestivum L.) yield depending on an integrated and intensive technology. The used production technologies differed as regards the nitrogen fertilization level, chemical protection against weeds, diseases, pests and the way of straw utilization. The following cultivars were selected for the research: 'Arabella' and 'KWS Torridon'. The weather conditions differentiated the yield of spring wheat in individual years. A higher effectiveness of intensive technology, expressed with a higher grain yield compared to the integrated one, was recorded in 2015 - on average by $18.0 \%$. The yield increase between intensive and integrated technologies resulted from a higher 1000 grain weight. Spring wheat cultivars showed a varied response to the production technologies used. Under the intensive technology, a significant yield increase was recorded for the cv. 'KWS Torridon', while the production technologies did not differentiate the yield of cv. 'Arabella'. The quantity and quality of protein substances and the activity of amylolitic enzymes in grains were more dependent on the cultivar than on the production technique used. In the case of spring wheat cultivars 'Arabella' and 'KWS Torridon', the integrated production technology ensures obtaining grains of the quality suitable for processing.
\end{abstract}

Key words: spring wheat, integrated technology, intensive technology, grain yield, grain quality.

\section{Introduction}

Common wheat (Triticum aestivum L.) is one of the most important cereal crops grown worldwide. This is due to its valuable chemical composition and exceptional technological properties. The harvesting of wheat depends to a large extent on the production technology used, therefore this cereal is cultivated in an intensive way, which is connected to a high consumption of industrial means of production, such as mineral fertilizers and plant protection products. Increased wheat production most often results in an increase in yields, but at the same time it poses many risks to both the environment and consumer health security. Organic and integrated production systems have been promoted in recent years as alternative, environmentally and human-friendly ways of management. The integrated production system limits the use of plant protection products to the necessary minimum, and adjusts the use of mineral fertilizers to the soil nutrient content and plant nutrition status. In this production system, a skillful combination of all technologies with a reduced consumption of industrial means of production should ensure efficiency of inputs incurred and minimize the negative impact of agriculture on the natural environment. The production system influenced the quality of the grain obtained and its possible use. Wheat grains from the integrated cultivation, in which nitrogen fertilization is reduced, may contain less protein substances than grains from the intensive cultivation, which may adversely affect their usefulness for processing (Jańczak, Pruszyński, \& Bubniewicz, 2002; Jańczak, Bubniewicz, \& Pruszyński, 2003; Jończyk, Kuś, \& Stalenga, 2007;
Korbas \& Mrówczyński, 2009; Kuś \& Jończyk, 2009; Cacak-Pietrzak, 2011).

The aim of the research was to analyze yields and selected parameters of technological value of two spring wheat cultivars grown under varied intensity of production technology.

\section{Materials and Methods}

The research was conducted in the years of $2015-$ 2016 at the Experimental Station in Osiny $\left(51^{\circ} 27^{\prime} \mathrm{N}\right.$; $22^{\circ} 2^{\prime} \mathrm{E}$ ), Poland. The experiment was located on lessive soil (Luvisol), on plots $45 \mathrm{~m}^{2}$ in size, in four replications. The soil had a slightly acid $\mathrm{pH}$ KCL (6.76) and included $1.66 \mathrm{mg}$ of $\mathrm{P}, 1.71 \mathrm{mg}$ of $\mathrm{K}$, and 1.08 of $\mathrm{C}_{\text {org }} \mathrm{g} \mathrm{kg}^{-1}$ of the soil. The first factor was the type of the technology: integrated and intensive (A), which was diversified in terms of the doses of mineral fertilizers and the intensity of plant chemical protection. The specification of treatments is given in Table 1. The second factor was 'Arabella' and 'KWS Torridon' (B) cultivars. Sowing was carried out after winter rape, from $17-24$ March with the Amazone drill. Sowing density was 400 seeds per 1 $\mathrm{m}^{2}$. Grain samples were collected directly after the harvest. The harvested area of plots for estimation of yield was $22.50 \mathrm{~m}^{2}$. Directly before the harvest, plant samples from the $1 \mathrm{~m}^{2}$ were taken and, based on biometric measurements, the number of ears per $\mathrm{m}^{2}$, the number of grains per ear and 1000 grain weight were determined.

The protein content was determined according to the Kjeldahl method with a Kjel-Foss Automatic (N.5.83) instrument of the AACC Method 46-11.02 


\section{Characterization of applied technologies for spring wheat production}

\begin{tabular}{|c|c|c|}
\hline \multirow{2}{*}{ Specification } & \multicolumn{2}{|c|}{ Technologies } \\
\hline & Integrated & Intensive \\
\hline Previous crop & \multicolumn{2}{|c|}{ winter rape } \\
\hline $\begin{array}{l}\text { Fertilization }\left(\mathrm{kg} \cdot \mathrm{ha}^{-1}\right) \\
\mathrm{N}(\text { ammonium nitrate) }\end{array}$ & $\begin{array}{c}50 \text { (in spring before sowing) } \\
40 \text { (at } \mathrm{BBCH} 31) \\
20(\text { at } \mathrm{BBCH} 51)\end{array}$ & $\begin{array}{c}60 \text { (in spring before sowing) } \\
60 \text { (at BBCH 31) } \\
40 \text { (at BBCH 51) }\end{array}$ \\
\hline $\begin{array}{l}\mathrm{P} \text { (superphosphate) } \\
\mathrm{K} \text { (potassium salt) }\end{array}$ & $\begin{array}{l}50 \mathrm{P}_{2} \mathrm{O}_{5} \\
105 \mathrm{~K}_{2} 0 \\
\end{array}$ & $\begin{array}{l}80 \mathrm{P}_{2} \mathrm{O}_{5} \\
100 \mathrm{~K}_{2} 0 \\
\end{array}$ \\
\hline Herbicide & $\begin{array}{l}\text { At BBCH 31: florasulan, aminopyralid } 2.4 \\
\qquad\left(0.81 \cdot \mathrm{ha}^{-1}\right)\end{array}$ & $\begin{array}{l}\text { At BBCH 31: florasulan, aminopyralid } 2.4 \\
\qquad\left(0.81 \cdot \mathrm{ha}^{-1}\right)\end{array}$ \\
\hline Fungicide & At BBCH 57: azoksystrobin $\left(0.61 \cdot \mathrm{ha}^{-1}\right)$ & $\begin{array}{l}\text { At BBCH 41: protiokonazol, spiroksamin } \\
\left(1.01 \cdot \mathrm{ha}^{-1}\right) \\
\text { BBCH 57: azoksystrobin }+ \text { propikonazol } \\
\text { cyprokonazol }\left(0.61 \cdot \mathrm{ha}^{-1}+0.41 \cdot \mathrm{ha}^{-1}\right)\end{array}$ \\
\hline Growth regulator & - & At BBCH 31: trineksapak etylu $\left(0.41 \cdot \mathrm{ha}^{-1}\right)$ \\
\hline Insecticide & At BBCH 51: zeta-cypermetryn $\left(0.11 \cdot\right.$ ha $\left.^{-1}\right)$ & At BBCH 51: zeta-cypermetryn $\left(0.11 \cdot\right.$ ha $\left.^{-1}\right)$ \\
\hline
\end{tabular}

(AACC 2010). The wet gluten content and gluten index of the samples were determined using Glutomatic 2200 of the AACC Method 38-12.02 (AACC 2010). The sedimentation value was obtained by the Zeleny of the AACC Method 56-61.02 (AACC 2010). The falling number was determined using the Falling Number Test Apparatus type 1400 of the AACC Method 56-81.03 (AACC 2010). The results were statistically analyzed using the two-factor variance analysis (Anowa) and Statgraphics Centurion XVI computer program. The significance of differences between the means was assessed using Tukey test at the significance level of $\mathrm{p}=0.05$.
Weather conditions during the development of spring wheat varied from year to year. The vegetation period in 2015 saw a higher amount of rainfall, similar to the mean of 1950 - 2000. Particularly favorable humidity and thermal conditions prevailed in May (during tillering, shoot formation) (Figures 1, 2). The growing period in 2016 was characterized by $1.6^{\circ} \mathrm{C}$ higher average air temperature and by $31 \mathrm{~mm}$ lower precipitation than the mean for many years. In the year of the study, particularly high air temperatures occurred in May and June, which was unfavourable for the development of wheat (Figures 1, 2).

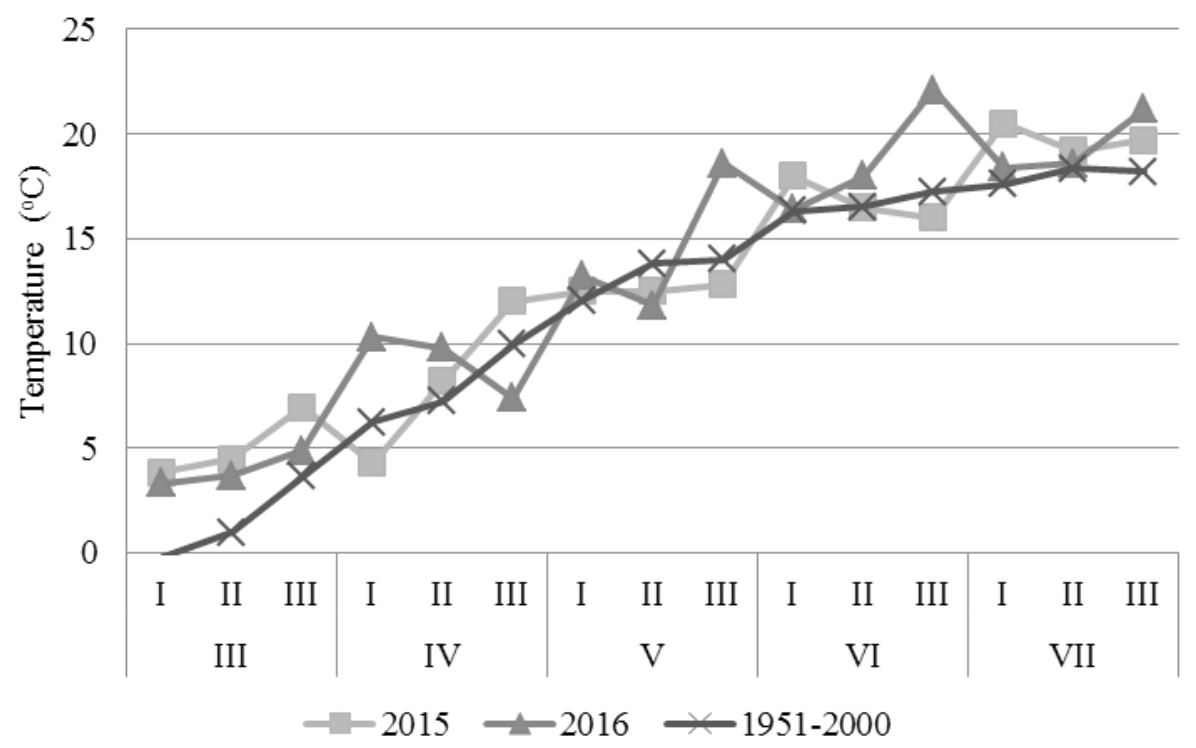

Figure 1 . Monthly average temperatures in 2015 - 2016 compared to the long-term average (1951 - 2000). 


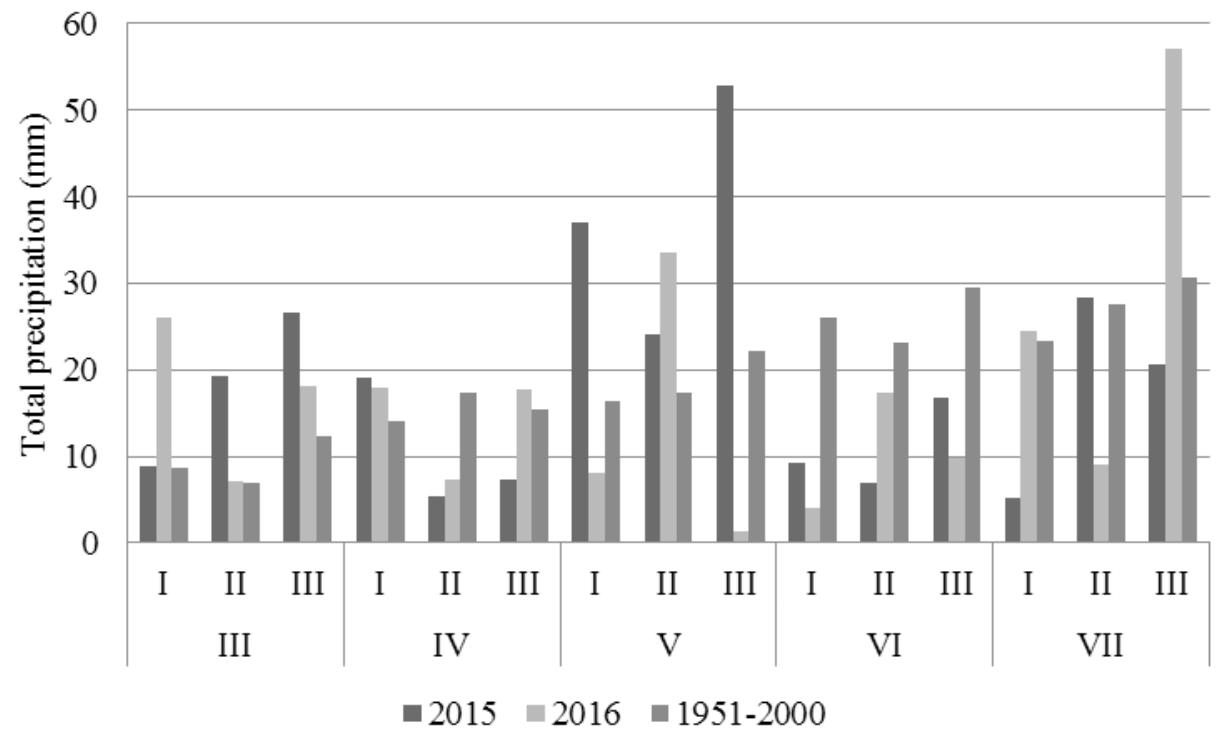

Figure 2. Monthly precipitation in 2015 - 2016 compared to the long-term average $(1951-2000)$.

\section{Results and Discussion}

The yield of spring wheat grain depended on the weather conditions in the years of research, intensity of production technology, and the cultivar (Table 2).

In 2015 , wheat yielded by $1.80 \%$ higher compared to 2016. The high impact of weather conditions on spring wheat yields has been confirmed by the results of studies by other authors (Jaskulski, 1999; Rudnicki, Jaskulski \& Dębowski, 1999). The authors point to a significant correlation between grain yield, the amount of precipitation in May and June, and the total precipitation in the period April - July. The optimum precipitation rate for wheat cultivated in heavy soil conditions from April to July is $151-200 \mathrm{~mm}$ (Panek, 1987). In 2015, no significant influence of production technologies on the yields of the tested spring wheat cultivars was found. In this year of the studies, spring wheat cultivars yielded at a similar level, with a tendency of higher yields of cv. 'KWS Torridon'. Wheat cv. 'Arabella' grown under the integrated technology yielded higher compared to the intensive technology, but this difference was not statistically significant. In the case of cv. 'KWS Torridon', the grain yield increased by $1.05 \mathrm{t}^{-\mathrm{ha}^{-1}}(14.6 \%)$ due to the intensification of cultivation. In 2016, spring wheat cultivars gave higher yields under the intensive production technology, but these differences were not statistically proven. In this year of the research, the grain yield of $\mathrm{cv}$. 'KWS Torridon' was by $1.27 \mathrm{t} \cdot \mathrm{ha}^{-1}$ higher in relation to cv. 'Arabella' (Table 2). Kołodziejczyk \& Szmigiel (2014) found that the application of higher nitrogen fertilization and fungicide protection contributed to an increase in grain yields on average by $1.49 \mathrm{t} \cdot \mathrm{ha}^{-1}$ $(26.5 \%)$. The varied reaction of spring wheat cultivars to the intensity of production technology, shown in this paper, had been confirmed in previous research (Cacak-Pietrzak \& Sułek, 2007; Kołodziejczyk, Szmigiel, \& Oleksy, 2007; Kołodziejczyk, Szmigiel, \& Kulig, 2009; Sułek \& Podolska, 2012).

The effect of intensity of production technology on the value of 1000 grain weight of spring wheat cultivars was noted in the year of higher yields (2015). In addition, in this year, the grain was the most mature. Wheat cv. 'KWS Torridon', cultivated under intensive technology, showed a significant increase in its 1000 grain weight (by 6.4\%) in relation to the integrated technology. In the case of cv. 'Arabella', no significant difference in this value was found among the different production techniques. In 2016, no effect of production technology on the 1000 grain weight was noted. In each year of the research, cv. 'KWS Torridon' was found to have a higher 1000 grain weight compared to cv. 'Arabella' (Table 2). In the studies of Dziki et al. (2017), spring wheat grain from the integrated production showed a higher 1000 grain weight in comparison with the grain from intensive cultivation, whereas in the studies of Cacak-Pietrzak \& Sułek (2007) and Marzec, Cacak-Pietrzak, \& Gondek (2011), the impact of production intensity on this quality of grain depended on the cultivar.

A significant increase in the ear density per unit area due to the intensification of production technology was found for cv. 'KWS Torridon'. However, the increase in intensity of production technology did not have a significant impact on the number of ears of cv. 'Arabella' (Table 2). Kołodziejczyk, Szmigiel, \& Oleksy (2007) indicate that the use of higher nitrogen fertilization and fungicide protection contributed to an increase in the number of ears per unit of area by, on average, $12.3 \%$. In our research, this increase was about $11.1 \%$. 
Grain yield of spring wheat cultivars depending on production technology in $2015-2016$

\begin{tabular}{|c|c|c|c|c|c|c|}
\hline \multirow{3}{*}{$\begin{array}{l}\text { Technology } \\
\text { production } \\
\text { (A) }\end{array}$} & \multicolumn{3}{|c|}{2015} & \multicolumn{3}{|c|}{2016} \\
\hline & \multicolumn{6}{|c|}{ Cultivars (B) } \\
\hline & Arabella & $\begin{array}{c}\text { KWS } \\
\text { Torridon }\end{array}$ & Means & Arabella & $\begin{array}{l}\text { KWS } \\
\text { Torridon }\end{array}$ & Means \\
\hline \multicolumn{7}{|c|}{ Grain yield $\left(\mathrm{t} \cdot \mathrm{ha}^{-1}\right)$} \\
\hline Integrated & 7.51 & 7.15 & 7.33 & 5.57 & 6.80 & 6.18 \\
\hline Intensive & 7.18 & 8.20 & 7.50 & 5.89 & 7.21 & 6.55 \\
\hline Means & 7.34 & 7.67 & & 5.69 & 7.10 & \\
\hline \multicolumn{4}{|c|}{$\mathrm{LSD}_{0.05}$ for $\mathrm{A}-$ n.s.; $\mathrm{B}-$ n.s.; $\mathrm{A} / \mathrm{B}-0.542$} & \multicolumn{3}{|c|}{$\mathrm{LSD}_{0.05}$ for A - n.s.; B - 1.257; A/B - 0.392} \\
\hline \multicolumn{7}{|c|}{1000 grain weight $(\mathrm{g})$} \\
\hline Integrated & 40.0 & 43.7 & 41.8 & 33.4 & 40.8 & 37.10 \\
\hline Intensive & 39.7 & 46.5 & 43.1 & 33.3 & 41.3 & 38.32 \\
\hline Means & 38.8 & 45.1 & & 34.4 & 41.0 & \\
\hline \multicolumn{4}{|c|}{$\mathrm{LSD}_{0.05}$ for $\mathrm{A}-$ n.s.; $\mathrm{B}-0.41 ; \mathrm{A} / \mathrm{B}-1.89$} & \multicolumn{3}{|c|}{$\mathrm{LSD}_{0.05}$ for $\mathrm{A}-$ n.s. $\mathrm{B}-4.21 ; \mathrm{A} / \mathrm{B}-\mathrm{n} . \mathrm{s}$} \\
\hline \multicolumn{7}{|c|}{ Number of ears per $\mathrm{m}^{2}$} \\
\hline Integrated & 566 & 468 & 517 & 604 & 449 & 526 \\
\hline Intensive & 572 & 510 & 530 & 614 & 556 & 585 \\
\hline Means & 569 & 489 & & 609 & 502 & \\
\hline \multicolumn{4}{|c|}{$\mathrm{LSD}_{0.05}$ for $\mathrm{A}-$ n.s.; $\mathrm{B}-37.8 ; \mathrm{A} / \mathrm{B}-39.3$} & \multicolumn{3}{|c|}{$\mathrm{LSD}_{0.05}$ for $\mathrm{A}-52.6 ; \mathrm{B}-63.8 ; \mathrm{A} / \mathrm{B}-71.2$} \\
\hline \multicolumn{7}{|c|}{ Number of grains per ear } \\
\hline Integrated & 36.5 & 35.0 & 35.5 & 27.6 & 37.1 & 32.3 \\
\hline Intensive & 31.6 & 34.6 & 33.3 & 29.3 & 31.4 & 30.3 \\
\hline Means & 34.0 & 34.8 & & 28.4 & 34.2 & \\
\hline \multicolumn{4}{|c|}{$\mathrm{LSD}_{0.05}$ for $\mathrm{A}-$ n.s.; $\mathrm{B}-$ n.s.; $\mathrm{A} / \mathrm{B}-$ n.s. } & \multicolumn{3}{|c|}{$\mathrm{LSD}_{0.05}$ for $\mathrm{A}-$ n.s.; $\mathrm{B}-3.92 ; \mathrm{A} / \mathrm{B}-4.77$} \\
\hline
\end{tabular}
n.s. - not significant

The presented research results concerning the number of grains per year show that the production technology did not influence this trait in 2015. In 2016, cv. 'KWS Torridon' grown under intensive technology (Table 2) showed a significantly higher number of grains. Earlier studies (Sułek \& Podolska, 2012) showed no relationship between the number of grains per ear and the intensity of production technology. These authors have shown that this feature depends on the cultivar. According to the research conducted by Kołodziejczyk, Szmigiel, \& Kulig (2009), using the intensive production technology results in a significant increase in the number of ears and grains per ear, whereas it has a negative impact on the 1000 grain weight.

The production technology of spring wheat did not significantly $(\mathrm{p}>0.05)$ affect the quality traits of grains, whereas the cultivar used shaped most traits of the grain quality, apart from the sedimentation index (Table 3). In both years of the research, the grains of cv. 'KWS Torridon' contained more total proteins than the grains of cv. 'Arabella' (Table 3). The influence of the cultivar features on the protein content in spring grains of wheat cultivars was also demonstrated by Uhlen et al. (2015). In 2015, the total protein content of grains was on average by 0.6 percentage points higher than in 2016, due to the weather conditions more favorable for the accumulation of protein. The use of intensive production technology resulted in an increase in the total protein content of grains of the tested wheat cultivars, but these changes were not statistically significant $(\mathrm{p}>0.05)$. Cacak-Pietrzak \& Sułek (2007), Marzec, Cacak-Pietrzak, \& Gondek (2011) and Dziki et al. (2017) demonstrated a beneficial effect of intensification of production on the total protein content in the grains of spring wheat cultivars. In this work, irrespective of the production technology used, the grain of both wheat cultivars met the requirements for the production of baking flour in terms of their total protein content (min. $11.5 \%$ of total protein).

The content of gluten proteins, similarly to total proteins, depended significantly on the cultivar features (Table 3). Significantly more gluten was 
Quality traits of spring wheat grains depending on production technology in 2015 - 2016

\begin{tabular}{|c|c|c|c|c|c|c|}
\hline \multirow{3}{*}{$\begin{array}{l}\text { Technology } \\
\text { production } \\
\text { (A) }\end{array}$} & \multicolumn{3}{|c|}{2015} & \multicolumn{3}{|c|}{2016} \\
\hline & \multicolumn{6}{|c|}{ Cultivars (B) } \\
\hline & Arabella & $\begin{array}{c}\text { KWS } \\
\text { Torridon }\end{array}$ & Means & Arabella & $\begin{array}{l}\text { KWS } \\
\text { Torridon }\end{array}$ & Means \\
\hline \multicolumn{7}{|c|}{ Protein content (\% s.s.) } \\
\hline Integrated & 12.1 & 13.5 & $12.8 \mathrm{a}$ & 11.5 & 12.8 & 12.2 \\
\hline Intensive & 12.8 & 13.9 & $13.3 \mathrm{a}$ & 11.8 & 13.7 & 12.7 \\
\hline Means & 12.5 & 13.7 & & 11.7 & 13.2 & \\
\hline \multicolumn{4}{|c|}{$\mathrm{LSD}_{0.05}$ for $\mathrm{A}-$ n.s.; $\mathrm{B}-0.85 ; \mathrm{A} / \mathrm{B}-$ n.s. } & \multicolumn{3}{|c|}{$\mathrm{LSD}_{0.05}$ for $\mathrm{A}-$ n.s.; $\mathrm{B}-0.71 ; \mathrm{A} / \mathrm{B}-0.82$} \\
\hline \multicolumn{7}{|c|}{ Gluten content $(\%)$} \\
\hline Integrated & 26.0 & 31.2 & 28.6 & 24.0 & 29.1 & 27.1 \\
\hline Intensive & 28.5 & 31.0 & 29.7 & 25.0 & 31.7 & 27.8 \\
\hline Means & 27.2 & 31.1 & & 24.5 & 30.4 & \\
\hline \multicolumn{4}{|c|}{$\mathrm{LSD}_{0.05}$ for $\mathrm{A}-\mathrm{n} . \mathrm{s} . ; \mathrm{B}-2.05 ; \mathrm{A} / \mathrm{B}-2.02$} & \multicolumn{3}{|c|}{$\mathrm{LSD}_{0.05}$ for $\mathrm{A}-$ n.s.; $\mathrm{B}-3.93 ; \mathrm{A} / \mathrm{B}-4.03$} \\
\hline \multicolumn{7}{|c|}{ Gluten index } \\
\hline Integrated & 99 & 79 & 89 & 99 & 86 & 93 \\
\hline Intensive & 98 & 68 & 83 & 98 & 85 & 92 \\
\hline Means & 99 & 74 & & 99 & 86 & \\
\hline \multicolumn{4}{|c|}{$\mathrm{LSD}_{0.05}$ for $\mathrm{A}-$ n.s.; $\mathrm{B}-19.3 ; \mathrm{A} / \mathrm{B}-10.3$} & \multicolumn{3}{|c|}{$\mathrm{LSD}_{0.05}$ for A - n.s.; B - n.s.; A/B - n.s. } \\
\hline \multicolumn{7}{|c|}{ Sedimentation value $\left(\mathrm{cm}^{3}\right)$} \\
\hline Integrated & 38 & 37 & 38 & 38 & 34 & 36 \\
\hline Intensive & 40 & 35 & 38 & 38 & 36 & 37 \\
\hline Means & 39 & 36 & & 38 & 35 & \\
\hline \multicolumn{4}{|c|}{$\mathrm{LSD}_{0.05}$ for $\mathrm{A}-$ n.s.; $\mathrm{B}-$ n.s.; $\mathrm{A} / \mathrm{B}-$ n.s. } & \multicolumn{3}{|c|}{$\mathrm{LSD}_{0.05}$ for A - n.s.; B - n.s.; A/B - n.s. } \\
\hline \multicolumn{7}{|c|}{ Falling number (s) } \\
\hline Integrated & 379 & 374 & 376 & 281 & 389 & 335 \\
\hline Intensive & 355 & 367 & 361 & 309 & 381 & 345 \\
\hline Means & 367 & 370 & & 295 & 385 & \\
\hline \multicolumn{4}{|c|}{$\mathrm{LSD}_{0.05}$ for $\mathrm{A}-$ n.s.; $\mathrm{B}-$ n.s.; $\mathrm{A} / \mathrm{B}$ - n.s. } & \multicolumn{3}{|c|}{$\mathrm{LSD}_{0.05}$ for $\mathrm{A}-\mathrm{n} . \mathrm{s} . ; \mathrm{B}-60.7 ; \mathrm{A} / \mathrm{B}-\mathrm{n} . \mathrm{s}$} \\
\hline
\end{tabular}

n.s. - not significant

removed from the grains of wheat cv. 'KWS Torridon' than from cv. 'Arabella'. Weather conditions in 2015 promoted the accumulation of gluten proteins in wheat grains more than in 2016. The use of intensive cultivation technology generally increased the amount of gluten proteins in the grains of the wheat cultivars studied, but the changes were not statistically significant. In previous studies (Cacak-Pietrzak \& Sułek, 2007), the amount of gluten proteins in spring wheat grains increased with the intensification of production technology, but at the same time their quality deteriorated. In this work, the deterioration of gluten quality was found only in the case of cv. 'KWS Torridon' grains from the 2015 harvest. Regardless of the year of research and the production technology used, the grain of both wheat cultivars were a suitable raw material for the production of baking flours in terms of the quantity and quality of gluten proteins.

The values of Zeleny's sedimentation index did not significantly depend on weather conditions in the years of research, the intensity of production technology, or cultivar (Table 3). In the previous studies (Cacak-Pietrzak \& Sułek, 2007), the values of this indicator depended on the cultivar, intensity of production technologies, and the interaction between these factors.

The activity of amylolitic enzymes in the grains of the tested wheat cultivars was generally at a low level (Table 3). An exception were the grains of cv. Arabella under the integrated cultivation, harvested in 2016, as they showed an average amylolitic activity. In the case of this cultivar, in 2016, intensification of the 
cultivation process significantly decreased the activity of amylolitic enzymes. In the previous studies (CacakPietrzak \& Sułek, 2007), the intensity of production technology did not have a significant impact on this characteristic of the grain, but, similarly as in the studies of Uhlen \& et al. (2015), it depended on the cultivar.

\section{Conclusions}

1. A higher effectiveness of intensive wheat production technology, expressed by the increase in grain yield (on average by $18.0 \%$ ) compared to the integrated technology, was noted in 2015. An increased grain yield was the result of a higher 1000 grain weight.

2. Spring wheat cultivars responded differently to the production technologies used. In the conditions of intensive production technology, cv. 'KWS Torridon' yielded significantly more, while the yields of cv. "Arabella" did not significantly differ.

3. The total protein content of the grains, including gluten proteins, depended on the cultivar characteristics. The grains of wheat cv. 'KWS Torridon' contained more of this component than the grains of cv. 'Arabella'. Using intensive production technology resulted in an increase in the content of protein substances of the analyzed wheat cultivars, but these changes were not statistically significant.

4. The activity of amylolitic enzymes in the grains of both analyzed wheat cultivars was at a low level, with the exception of 'Arabella' cultivar grown under the integrated system in the 2016 harvest. In this study, the use of intensive production technology significantly decreased the amylolitic activity of the grains.

5. The research showed that the use of integrated production technology did not adversely affect the quality characteristics of the grains of the tested cultivars of spring wheat. The intensification of production technology can only be justified in the case of wheat cv. 'KWS Torridon' due to its higher yields under this system.

\section{References}

1. AACC (2010). Method 38-12.02: Wet gluten, Dry Gluten, Water - Binding Capacity, and Gluten Index. Method 46-11.02: Crude Protein - Improved Kjeldahl Method, Copper Catalyst Modyfication. Method 5681.03: Determination of Falling Number. Method 56-61.02: Sedimentation Test for Wheat. 11th Edition. Official Methods of the American Association of Cereal Chemists. St. Paul. MN, USA.

2. Cacak-Pietrzak, G. (2011). Studia nad wpływem ekologicznego i konwencjonalnego systemu produkcji roślinnej na wartość technologiczną wybranych odmian pszenicy. Rozprawy i monografie. (Studies on the effect of ecological and conventional system of plant production on the technological value of selected varieties of winter wheat. Treatises and Monographs). Wydawnictwo SGGW, Warszawa, 1-83. (in Polish).

3. Cacak-Pietrzak, G., \& Sułek, A. (2007). Wpływ poziomu nawożenia azotem na plonowanie i jakość technologiczną ziarna pszenicy jarej (The effect of nitrogen fertilization on yield and technological parameters of spring wheat). Biuletyn Instytutu Hodowli i Aklimatyzacji Roślin, 243, 47-55. (in Polish).

4. Dziki, D., Cacak-Pietrzak, G., Gawlik-Dziki, U., Świeca, M., Miś, A., Różyło, R., \& Jończyk, K. (2017). Physicochemical properties and milling characteristics of spring wheat from different farming systems. Journal of Agricultural Science and Technology, 19, 6, 1253-1266. DOI: jast-old.modares.ac.ir/ article_17233_5512.html.

5. Integrowana produkcja pszenicy ozimej i jarej. (2009). (Korbas M. i Mrówczyński M. red.) (Integrated production of winter and spring wheat). Wydawnictwo Instytutu Ochrony Roślin, Poznań. (in Polish).

6. Jańczak, C., Pruszyński, S., \& Bubniewicz, P. (2002). Winter wheat protection against diseases and pests in conventional programme of crop protection and in integrated pest management. Plant Protection Science, 38 (1), 221-226.

7. Jańczak, C., Bubniewicz, P., \& Pruszyński, S. (2003). Uwarunkowanie wdrożenia integrowanego programu ochrony pszenicy ozimej (Conditioning oft he implementation oft he integrated program fort he protection of winter wheat). Progress Plant Protection, 43 (1), 146-150. (in Polish).

8. Jaskulski, D. (1999). Wpływ terminu siewu i gęstości siewu oraz nawożenia azotem na plonowanie pszenicy jarej w warunkach małej ilości opadów (The effect of seeding date and nitrogen fertilization on the yield of spring wheat at limited rainfull). Pamiętnik Puławski, 118, 167-172. (in Polish).

9. Jończyk, K., Kuś, J., \& Stalenga, J. (2007). Produkcyjne i środowiskowe skutki różnych systemów gospodarowania (Production and environmental effects of various management systems). Problemy Inżynierii. Rolniczej, 1, 13-22. (in Polish).

10. Kołodziejczyk, M., Szmigiel, A., \& Oleksy, A. (2007). Wpływ intensywności uprawy na plonowanie wybranych odmian pszenicy jarej (Efect of cultivation intensity on yielding of some spring wheat cultivars) Acta Scintiarum. Polonorum., Agricultura, 6 (4), 5-4. (in Polish). 
11. Kołodziejczyk, M., Szmigiel, A., \& Kulig, B. (2009). Plonowanie wybranych odmian pszenicy jarej w zależności od poziomu agrotechniki (Yielding of selected spring wheat cultivars depending on technology level). Fragmenta Agronomica, 26 (3), 58-67. (in Polish).

12. Kołodziejczyk, M., \& Szmigiel, A. (2014). Wpływ intensywności technologii uprawy na plonowanie wybranych odmian pszenicy jarej (Influence of intensity cultivation technology of some spring wheat cultivars). Fragmenta Agronomica, 31 (3), 75-84. (in Polish).

13. Kuś, J., \& Jończyk, K. (2009). Produkcyjne i środowiskowe następstwa ekologicznego, integrowanego i konwencjonalnego systemu gospodarowania (Production and environmental consequence oft he ecologial and conventional crop production systems). Journal Resarch Application in Agricultural Engineering, 54 (3), 183-187. (in Polish).

14. Marzec, A., Cacak-Pietrzak, G., \& Gondek, E. (2011). Mechanical and acoustic properties of spring wheat versus ist technological quality factors. Journal of Texture Studies, 42, 4, 319-329. DOI: 10.1111/j.17454603.2011.00284.x

15. Panek, K. (1987). Wpływ ilości opadów na plonowanie zbóż w zależności od poziomu nawożenia , zwięzłosci gleby i rejonu uprawy (Influence of the amount of precipitation on yielding of cereals depending on the level of fertilization, soil compactness and area of cultivation). Zeszyty Problemowe Postęów Nauk Rolniczych, 314, 119-136. (in Polish).

16. Rudnicki, F., Jaskulski, D., \& Dębowski, G. (1999). Reakcje odmian pszenicy jarej na termin siewu i nawożenie azotem w warunkach posusznych (Reactions of spring wheat varieties to the sowing date and nitrogen fertilization in dry conditions). Roczniki Nauk Rolniczych, A 114, 97-108. (in Polish).

17. Sułek, A., \& Podolska, G. (2012). Wpływ integrowanej technologii produkcji na plonowanie odmian pszenicy jarej (The infuence of production technology on yielding of spring wheat cultivars). Progres Plant Protection, 52 (4), 945-950. (in Polish).

18. Uhlen, A., Dieseth, J., Koga, S., Böcker, U., Hoel, B., Anderson, J., \& Moldestad, A. (2015). Variation in gluten quality parameters of spring wheat varieties of different origin grown in contrasting environments. Journal of Cereal Science, 62, 110-116. DOI: 10.1016/j.jcs.2015.01.00. 